\title{
ケナフ勒皮繊維の中間ラメラへの水熱処理の影響
}

\author{
京都市産業技術研究所 南 秀明・西内滋典・門野純一郎 \\ 京都工芸繊維大学大学院 工芸科学研究科応用生物学部門 杉村順夫 \\ 群馬大学大学院 工学研究科応用化学・生物化学専攻 河原 豊
}

\section{Influence of Hydrothermal Treatments on the Chemical Composition of Intercellular Matrix Regions of Kenaf Fibers}

\author{
Hideaki Minami $^{* 1}$, Shigenori Nishiuchi ${ }^{* 1}$, Junichiro Kadono ${ }^{* 1}$, Yukio Sugimura ${ }^{* 2}$, and Yutaka Kawahara ${ }^{* 3}$ \\ ${ }^{* 1}$ Kyoto Municipal Industrial Research Institute, 134, Chudoji-minami-machi, Shimogyo-ku, \\ Kyoto 600-8813, Japan \\ ${ }^{* 2}$ Department of Applied Biology, Graduate School of Science and Technology, Kyoto Institute of \\ Technology, Matsugasaki, Sakyo-ku, Kyoto 606-8585, Japan \\ ${ }^{* 3}$ Department of Biological \& Chemical Engineering, Graduate School of Engineering, Gunma University, \\ 1-5-1, Tenjin, Kiryu, Gunma 376-8515, Japan
}

\begin{abstract}
The influence of hydrothermal treatments on the chemical composition of intercellular matrix regions of kenaf fibers was investigated. The treatment using the hot stream of water vapor was more effective to dissolve hemicellulose fractions as compared with the treatments in hot pressurized water. On the contrary the dissolution of lignin fractions and calcium was fairly suppressed in the case of water vapor. These results suggest that the retting of kenaf fibers using hot water vapor will accompany the partial destruction of intercellular matrix although the treatment with hot pressurized water will bring about the complete destruction of the matrix.
\end{abstract}

(Received 21 May, 2009; Accepted 7 August, 2009)

\section{1. 緒 言}

植物繊維でプラスチックを強化した環境材料の開発が イツの自動車産業を中心に進められ $[1,2]$, 我が国でも積 極的に実用化され始めている．強化繊維としてケナフは, ジュートなどと同様に，繊維を採取することが容易なた め注目されているが, ヘミセルロースとリグニンで構成 されている繊維細胞間の中間ラメラが化学的に不安定な ため [3], 強化繊維として用いる場合, 製造工程において 注意が必要である。一方, マトリックス樹脂は植物繊維 の水分によって加水分解を生じないポリプロピレンを主 として用いているが, ポリ乳酸を用いるときは繊維の乾 燥を十分に行っておく必要がある。

植物繊維からフィラーを製造する方法としては，粉砕 によって物理的に行う方法と, 水熱反応によって繊維細 胞間の膠着物質を除去する方法が考えられる. 既報 [4]に おいて, ジュート繊維に水熱処理を行うことで, 繊維細 胞間の中間ラメラが崩壊して短繊維化することを確認し た. 崩壊のメカニズムとして，中間ラメラを安定化させ ているカルシウムの溶出が大きく影響していることを確 認した．植物繊維をフィラーとして用いる場合，表層の
柔細胞の除去 (レッティング)は樹脂との界面の接着性を 考慮すると必須であるが, 纎維細胞間を膠着する中間ラ メラの機能は, 出来るだけ温存してフィラーの脆化は回 避しなければならない, そこで, 本研究では, ケナフ鞎 皮繊維に対して, 水熱処理条件を検討し, 中間ラメラの 崩壊を抑制しながら柔細胞の除去が可能な処理方法の検 討を行った。

\section{2. 実 験}

\section{1 試料}

京都工芸繊維大学, 生物資源フィールド科学教育研究 センターで栽培されたケナフ (Hibiscus cannabinus L. cv.中 雑紅 305）を用いた。屋外水路に採取した茎部を浸漬し, 微生物の発酵を利用するバクテリアレッティング法によ り勒皮部を粗分離し，風乾して試料とした.

\section{2 水熱処理}

テフロン製内張りステンレス容器(容積 $30 \mathrm{ml}$, 四国理 科製)にケナフ緎維 $0.3 \mathrm{~g}$ と蒸留水 $10 \mathrm{ml}$ を加え, 密閉式高 温高圧水反応処理装置 (OSK-500, 四国理科製)に固定して, $100 \sim 220^{\circ} \mathrm{C}, 1$ 時間の水熱処理を行った。なお，この水 
熱反応処理装置は, 炉内の回転軸によって, ステンレス 容器を回転させて, 内容物を攪拌することができる. 今 回は, (1)高温水中で覺拌あり，（2）高温水中(攪汼なし), (3) 水蒸気の 3 水準で水熱処理を行った(Table.1).

\section{3 測定}

水熱処理後, 繊維については, 蛍光 X 線分析, 走査電 子顕微鏡 $(\mathrm{SEM})$ 観察, 赤外吸収スペクトル $(\mathrm{FT}-\mathrm{IR})$ 測定を 行い, 処理液については, $\mathrm{pH}$, 紫外吸収スペクトル (UV), 無機成分，有機酸成分の測定を行った.

蛍光 $\mathrm{X}$ 線分析は, 室温で風乾した繊維を, 試料ホルダー に保持し, リガク製 ZSX Primus II を用いて, ファンダメ ンタルパラメータ法で定性分析した.

SEM 観察は, 室温で風乾した試料を, カーボンテープで 固定し, 金蒸着後, 日本電子製 JSM-5900LV を用いて行っ た。

FT-IR 測定は, 室温で風乾した試料の表層について, Diamond ATR 法(パーキンエルマー製 System 2000, 測定 条件: 積分回数 8 回, 分解能: $4 \mathrm{~cm}^{-1}$, 検出器: TGS) で測 定した。

UV 測定は, 蒸留水を用いて, 処理液を 50 倍, 100 倍, 200 倍に希釈し, 蒸留水をリファレンスにして, 島津製作 所製 UV-3000を用いて測定した.

有機酸測定は, 蒸留水を用いて, 処理液を測定に最適な 濃度に希釈し，日本ダイオネクス製イオンクロマトグラ フ 4500i を用いて, 測定条件(陰イオン交換カラム [IonPac $\mathrm{AG} 4 \mathrm{~A}, \mathrm{AS} 4 \mathrm{~A}]$, 溶離液: $1.0 \mathrm{mM}-\mathrm{NaHCO}_{3}$, 流速: $1.5 \mathrm{ml} / 1$, 試料注入量 : $25 \mu \mathrm{l}$, 再生液サプレッサー法[硫酸])にて測 定した。

無機成分の定量は, サーモフィッシャーサイエンティ フィック製 ICP 発光分析装置 IRIS/AP Advantage を用いて 測定した，繊維試料については，灰化した後，硝酸で酸 溶解して測定溶液を調製した。測定溶液及び処理液は, 測定に最適な濃度に希釈し, 硝酸で酸濃度を調整して測 定した.

Table 1 Hydrothermal treatment conditions.

\begin{tabular}{|c|c|}
\hline Mode & Procedure \\
\hline Rotating & $\begin{array}{l}\text { The treatment was made rotating the vessel } \\
\text { at a speed of } 12 \mathrm{rpm} .\end{array}$ \\
\hline $\begin{array}{l}\text { Without } \\
\text { rotating }\end{array}$ & $\begin{array}{l}\text { The treatment was made settling the vessel } \\
\text { stable to keep dipping the fibers in water. }\end{array}$ \\
\hline $\begin{array}{l}\text { Water } \\
\text { vapor }\end{array}$ & $\begin{array}{l}\text { The treatment was made using the vessel } \\
\text { separated into upper and lower portions by } \\
\text { inserting the Teflon mesh. The fibers were } \\
\text { put into the upper portion to prevent from } \\
\text { dipping in water and to expose to the } \\
\text { stream of water vapor. }\end{array}$ \\
\hline
\end{tabular}

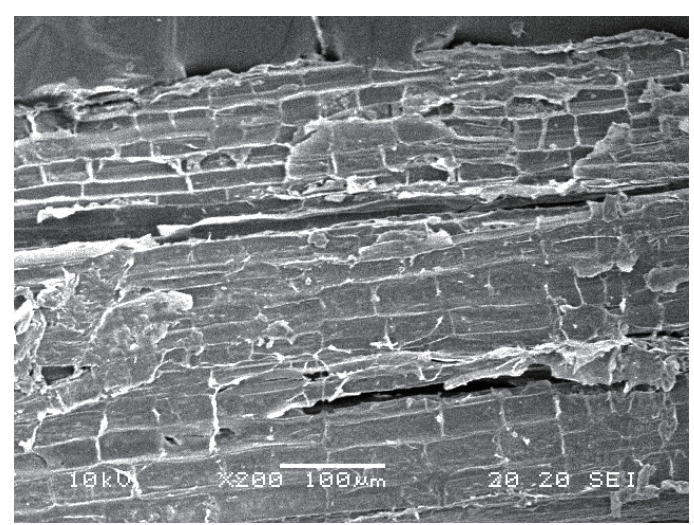

Fig. 1 Scanning electron micrograph for as-retted kenaf fibers. The scale bar corresponds to $100 \mu \mathrm{m}$.

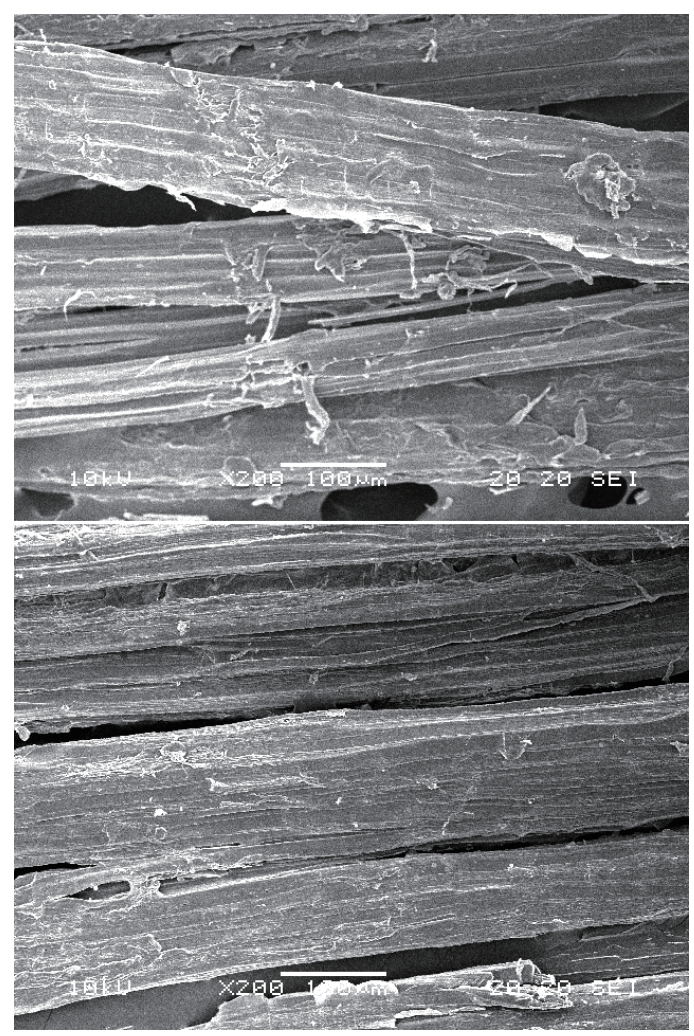

Fig. 2 Scanning electron micrographs for kenaf fibers hydrothermally treated for $1 \mathrm{~h}$ at $160{ }^{\circ} \mathrm{C}$ : top, with rotating; bottom, without rotating the vessel. Each scale bar corresponds to $100 \mu \mathrm{m}$.

\section{3. 結果および考察}

\section{1 水熱処理した繊維のキャラクタリゼーション \\ 3.1 .1 繊維形態の変化}

バクテリアレッティング後, ケナフの茎から引き裂い て分離した勒皮繊維束の側面には, 隣接する柔細胞壁の 残骸の付着が認められた (Fig. 1). 水熱処理による纎維表 面の変化を Fig. 2〜 4 に示す. 高温水中での攪拌の影響に ついては, Fig. 2 に示すように, 繊維形態は同様であり, 基本的に $160{ }^{\circ} \mathrm{C}$ でほほ柔細胞の細胞壁の脱離が完了し, 平滑な繊維表面となった. さらに, 高温で処理すると, Fig. 3 に示すように, 部分的な繊維細胞間の開裂と球状の分解 


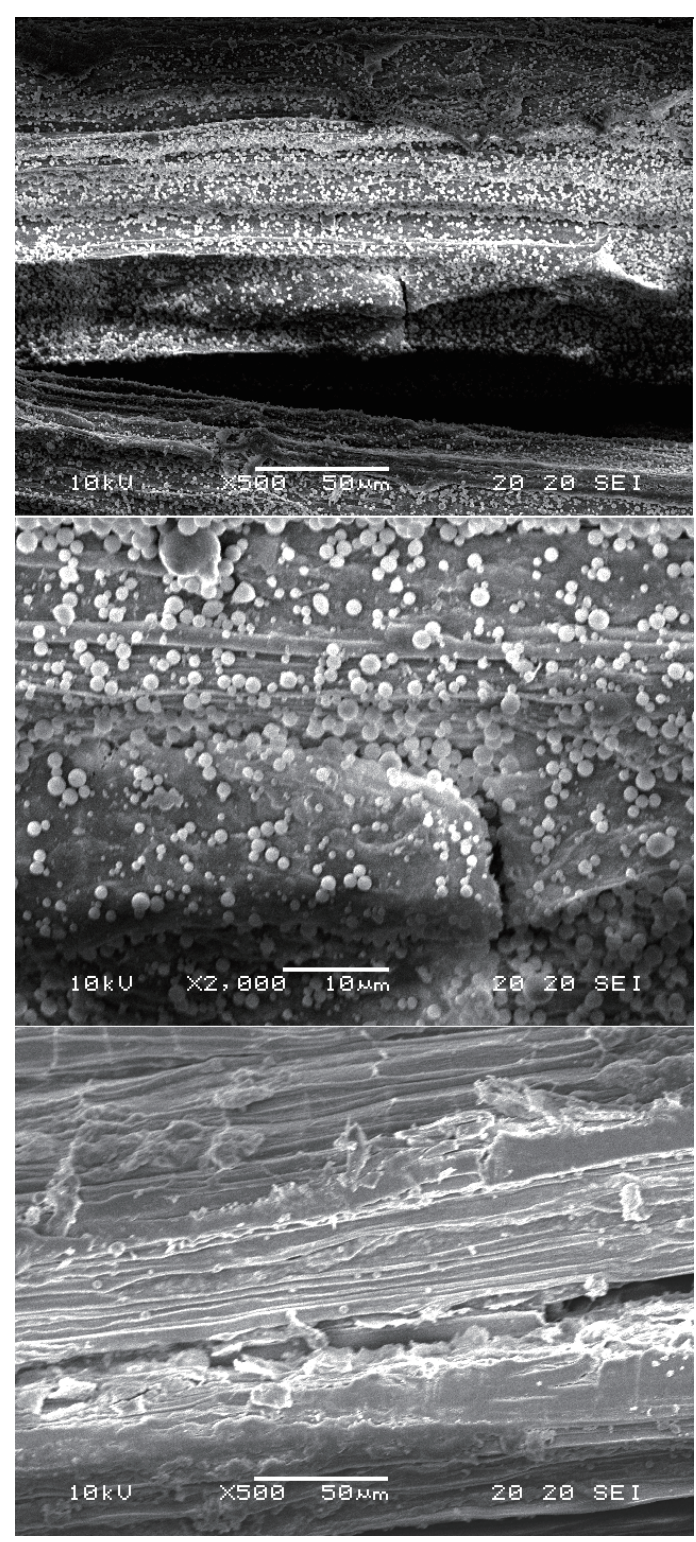

Fig. 3 Scanning electron micrographs for kenaf fibers hydrothermally treated without rotating the vessel for $1 \mathrm{~h}$ : top and middle, at 200 ; bottom, at $220{ }^{\circ} \mathrm{C}$.

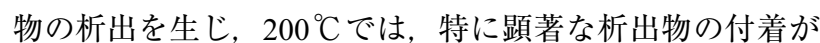

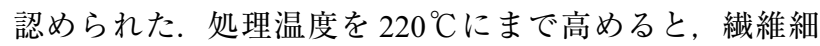
胞間の開裂がさらに進むため, 緎維内部からの分解物の 浴中への遊離が容易となり，見かけ上，瀻維表面は平滑 になった．この繊維表面の変化は, 既報[4]のジュートの 場合と同様であった。

一方，水蒸気処理した場合においても同様な形態変化

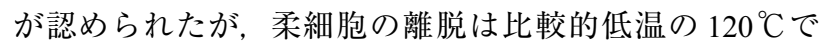
生じ，平滑な表面が得られた(Fig. 4 上段)。一方， $200^{\circ} \mathrm{C}$ での分解物の析出はそれほど顕著ではなかった (Fig.4下 段).

\subsection{2 表面官能基}

Fig. 5 に，水熱処理した瀻維表面の赤外吸収スペクトル を示す. $1595 \mathrm{~cm}^{-1}$ および $1509 \sim 1507 \mathrm{~cm}^{-1}$ の吸収スペクト ルは，共にリグニン由来の芳香環伸縮帯に対応し $[5,6]$,

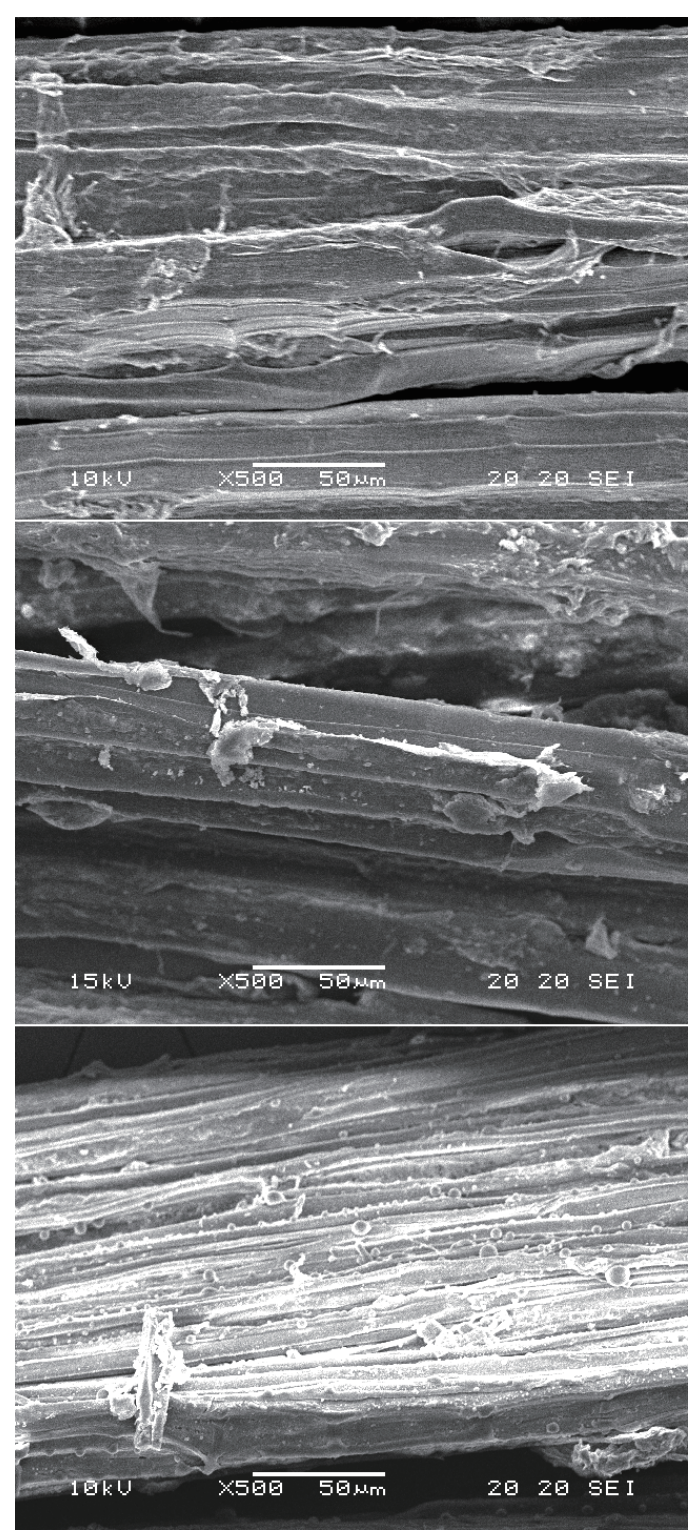

Fig. 4 Scanning electron micrographs for kenaf fibers hydrothermally treated in the stream of water vapor for $1 \mathrm{~h}$ : top, at 120 ; middle, at 160 ; bottom, at $200{ }^{\circ} \mathrm{C}$.

1240 $1235 \mathrm{~cm}^{-1}$ は，芳香族メトキシ基の C-O 伸縮に対応 する[5]. したがって，ケナフ繊維には，グアイアシルリ グニンあるいはシリンギルリグニンが含まれていること がわかる。 また，1735〜 $1718 \mathrm{~cm}^{-1}$ の吸収スペクトルは, エステルカルボニルの $\mathrm{C}=\mathrm{O}$ 伸縮に対応することから, へ ミセルロースのアセチル基に由来すると判断される [7].

水熱処理を行うと基本的にリグニンに対応した $1238 \mathrm{~cm}^{-1}$ 及び $1595 \mathrm{~cm}^{-1}$ のピーク, ヘミセルロースに対応 した $1728 \mathrm{~cm}^{-1}$ のピークが $180 \sim 200^{\circ} \mathrm{C}$ 以上の処理温度にお いて，急激に低下することがわかる。これは，中間ラメ ラを構成する Lignin-carbohydrate-complex (LCC)が高温で 破壊され，溶出したことに起因する $[8] .3$ 種類の水熱処 理条件の影響について比較検討すると, リグニンのピー クについては同様であるが, ヘミセルロースについては, Fig. 5 下段の水蒸気処理の場合, 他が $220^{\circ} \mathrm{C}$ であるのに対 

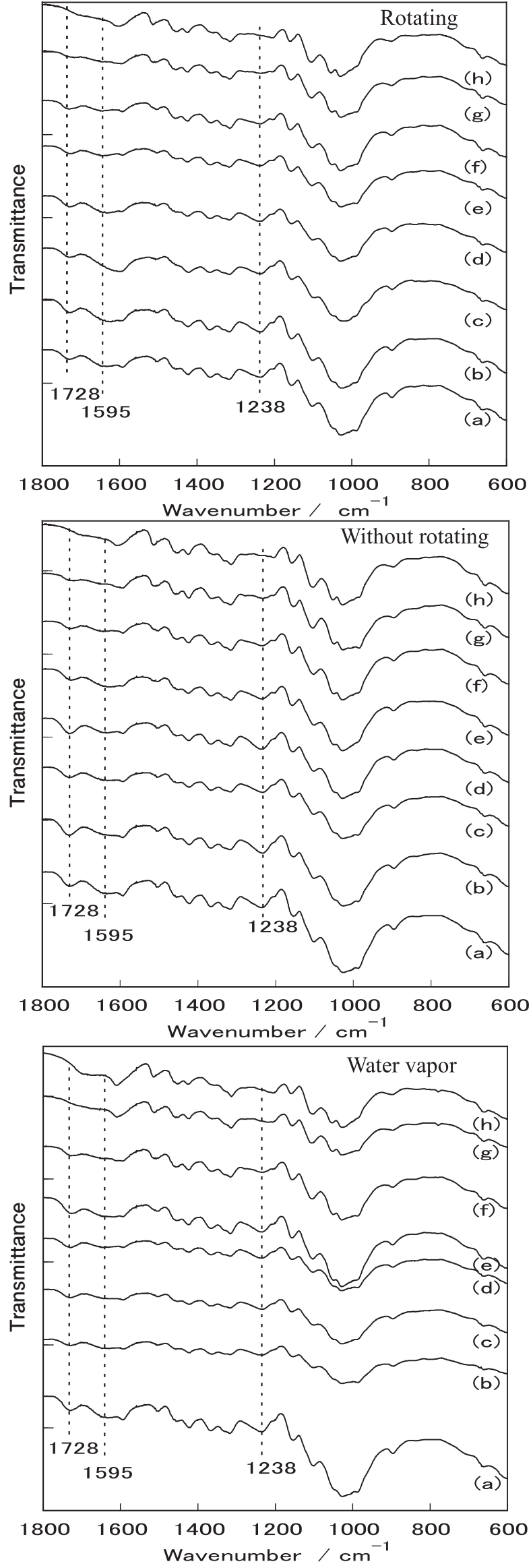

Fig. 5 Infrared spectra of kenaf fibers : a, control and the fibers hydrothermally treated in each mode for $1 \mathrm{~h}$ at $\mathrm{b}, 100 ; \mathrm{c}, 120 ; \mathrm{d}, 140 ; \mathrm{e}, 160$; f, $180 ; \mathrm{g}, 200 ; \mathrm{h}, 220{ }^{\circ} \mathrm{C}$.

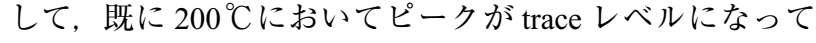
おり, ヘミセルロースの溶出が進んでいることが示唆さ れる.つまり, 水蒸気処理の方が, 高温水処理に比べて, ややへミセルロースが溶出され易いのではないかと推測 される。

ヘミセルロースは細胞間の固着物質であり, その溶出 が水蒸気処理の場合, より進行しやすいと考えれば，処 理後の繊維表面の観察において, 柔細胞の脱離が $120^{\circ} \mathrm{C}$ で認められたことと矛盾しない.

\subsection{3 無機成分量}

バクテリアレッティング後の繊維に含まれる無機成分 について，蛍光 X 線分析法で定性 (半定量) 分析を行った ところ，主に， $\mathrm{Ca}, \mathrm{Fe}, \mathrm{Na}, \mathrm{Si}$ が検出された。この中で, カルシウムは, 中間ラメラの安定化に重要である [4,9]. そこで, 水熱処理後の繊維中の $\mathrm{Ca}$ 量の変化について ICP 発光分析法により定量測定し, 風乾した繊維中の重量分 率として Fig. 6 に示す. $120^{\circ} \mathrm{C}$ までは熱処理方法の違いに よる $\mathrm{Ca}$ 量の差は認められず, $0.2 \%$ 前後の值となった. $140^{\circ} \mathrm{C}$ を超えると, 高温水処理では試料の攪拌の有無に関 わらず, $\mathrm{Ca}$ 量が減少し $200{ }^{\circ} \mathrm{C}$ では trace レベルにまで低下 した. 一方, 水蒸気処理では, 検出量に変動はあるもの の, $200^{\circ} \mathrm{C}$ 以上の高温処理においても明確に $\mathrm{Ca}$ が検出さ れた．Ca は LCC とキレートして中間ラメラを安定化させ る役割がある [3]. 従って, 纎維中の $\mathrm{Ca}$ 量の減少は繊維 細胞間を接合している中間ラメラの崩壊を示唆する. 水 蒸気処理では, 中間ラメラへの損傷がある程度抑えられ ていると考えられる.

\section{2 溶出成分のキャラクタリゼーション \\ 3.2.1 有機酸}

水熱処理前の系の $\mathrm{pH}$ は, 約 6.1 であったが, 処理後の pH を測定したところ, Fig. 7 に示す様に酸性側にシフト したことがわかる，処理液の $\mathrm{pH}$ の低下は，纎維から分解 生成した有機酸のためではないかと考えられる．処理液 をイオンクロマトグラフィーを用いて測定し，ギ酸につ

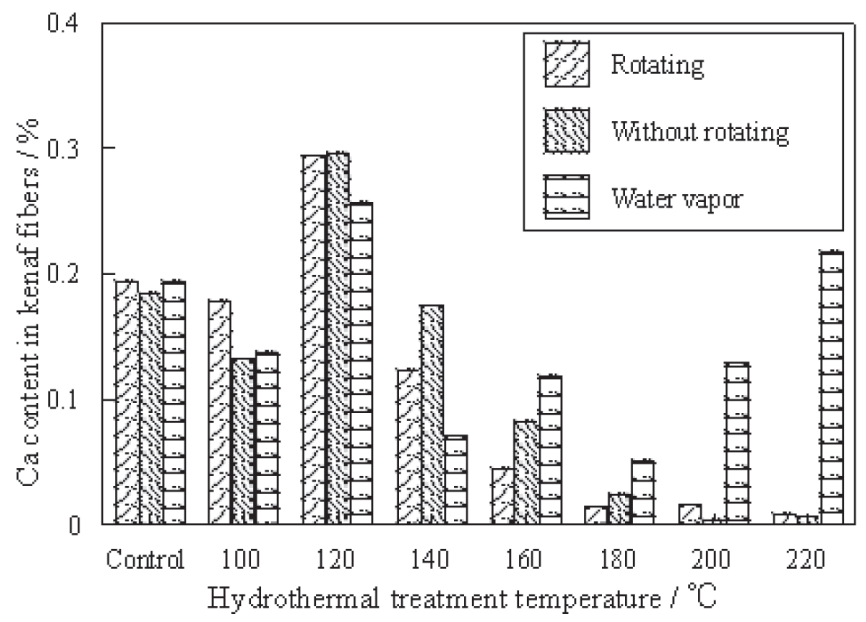

Fig. 6 Calcium contents in kenaf fibers estimated from ICP-AES measurements after hydrothermal treatment for $1 \mathrm{~h}$. 


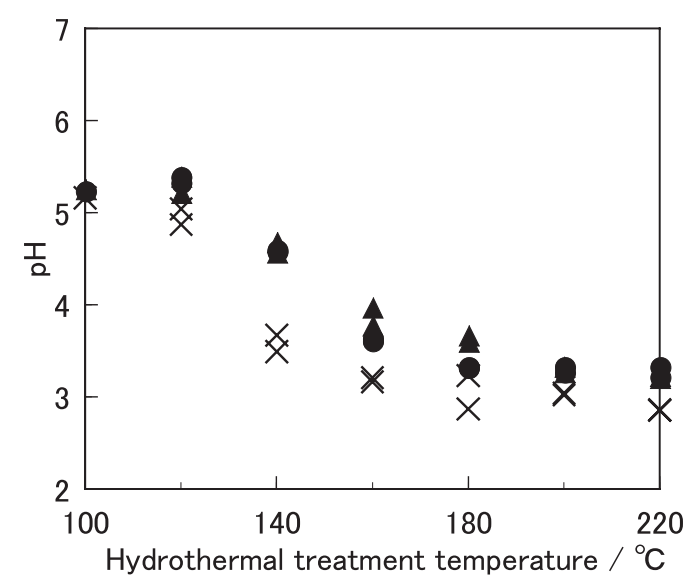

Fig. $7 \mathrm{pH}$ of the bath measured after the hydrothermal treatment: $\boldsymbol{\bullet}$, with rotating; $\boldsymbol{\Delta}$, without rotating the vessel; $\times$, in water vapor stream.

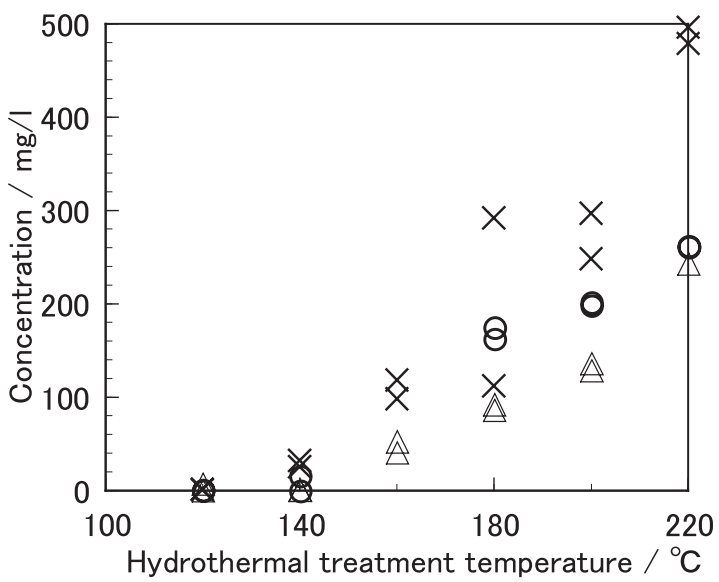

Fig. 8 Concentration of formic acid derived during the hydrothermal treatment: $\bigcirc$, with rotating; $\triangle$, without rotating the vessel; $\times$, in water vapor stream.

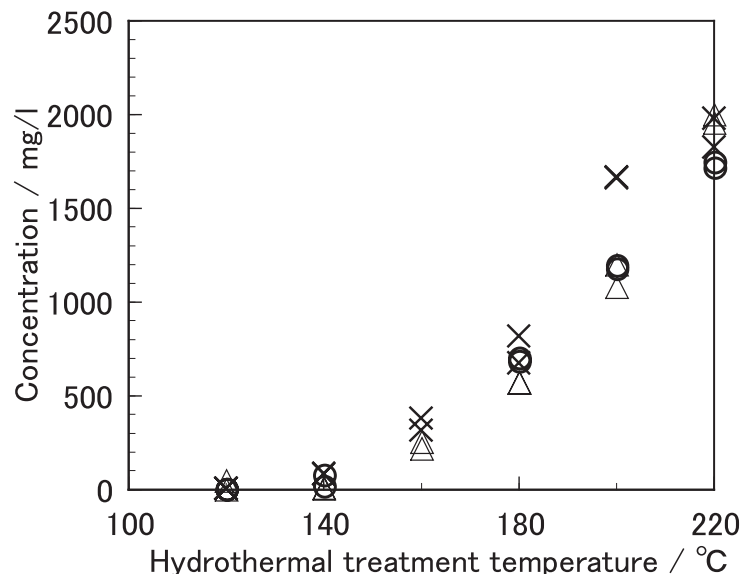

Fig. 9 Concentration of acetic acid derived during the hydrothermal treatment: $\bigcirc$, with rotating; $\triangle$, without rotating the vessel; $\times$, in water vapor stream.
いては Fig. 8 に, 酢酸については Fig. 9 に示す. 検出量が 処理温度の上昇に伴って高くなることがわかる.なお, これらの有機酸は, ジュート繊維を水熱処理したときも 同様に検出された 44$]$. ギ酸は, リグニン側鎖の第 1 級ア ルコールから生じたホルムアルデヒドが, さらに空気酸 化して生成したのではないかと考えられる，また，酢酸 は, ヘミセルロースに含まれるアセチル基由来と考えら れる $[10]$.

水熱処理条件の影響については, 水蒸気処理の場合, $140{ }^{\circ} \mathrm{C}$ 処理で検出されるようになり, その後も他の条件に 比べて，検出量が常に多いことがわかる.

\section{2 .2 リグニン}

水熱処理後の処理液の UV スペクトルの測定結果を Fig. 10 に示す. いずれの水熱処理条件においても $205 \mathrm{~nm}$, $280 \mathrm{~nm}$ 付近に溶出成分による吸収ピークが観測された. これら2つのピークは, リグニンのエチレンバンド $(205 \mathrm{~nm})$ 及びベンゾイドバンド $(280 \mathrm{~nm})$ に対応しており, ジュート繊維のときと同様に, リグニンが含まれている ことがわかる [4]. スペクトルピークの高さを比較して, (3) 水蒸気処理の場合, 最も低く, リグニンの溶出量が少 ないことがわかる.

溶出液のベゾイドバンドの吸収ピークは $276 \mathrm{~nm}$ にあり, グアイアシルリグニン $(280 \mathrm{~nm})$ とシリンギルリグニン $(274 \mathrm{~nm})$ の各々の吸収ピークの中間に位置することから， 処理液中にはグアイアシルリグニンとシリンギルリグニ ンの両方が含まれていると考えられる $[4,11]$.

\subsection{3 カルシウム}

中間ラメラの安定化には, $\mathrm{Ca}$ が深く関わっていること から, 水熱処理で中間ラメラに損傷があれば, 処理液中 への $\mathrm{Ca}$ の溶出に反映されると予想される. そこで, 水熱 処理後の処理液に含まれる $\mathrm{Ca}$ 濃度を ICP 発光分析法によ り定量測定した(Fig. 11). 繊維が高温高圧水で処理された ときは攪拌の有無によらず, $140^{\circ} \mathrm{C}$ を超えると $\mathrm{Ca}$ の検出 量が急増した. この変化は, Fig. 6 において同様の処理を 行った繊維中の $\mathrm{Ca}$ 含有率が低下し始めたことに対応して いる. この処理系では LCCへの損傷が著しいことがわか る. 一方, 水蒸気で処理した場合においては, $\mathrm{Ca}$ の溶出 が $140^{\circ} \mathrm{C}$ から検出され, 極大を示した後 $220^{\circ} \mathrm{C}$ で減少す る.この变化は, Fig. 6 の水蒸気処理した纎維の $\mathrm{Ca}$ 含有 率が $180^{\circ} \mathrm{C}$ で極小となった後, 回復していることと対応 していて興味深い. 極值を生じる原因については今後さ らに検討する必要があるが, 少なくとも水蒸気処理では, 中間ラメラは部分的に破壊される程度であると考えられ る.

\section{4. 結 言}

水熱条件を検討した結果, $120^{\circ} \mathrm{C} \cdot 1$ 時間の水蒸気処理 を行うことで, ケナフ䋊維の中間ラメラを構成する LCC の破壊や LCC と錯体を形成し, 中間ラメラの安定化に重 

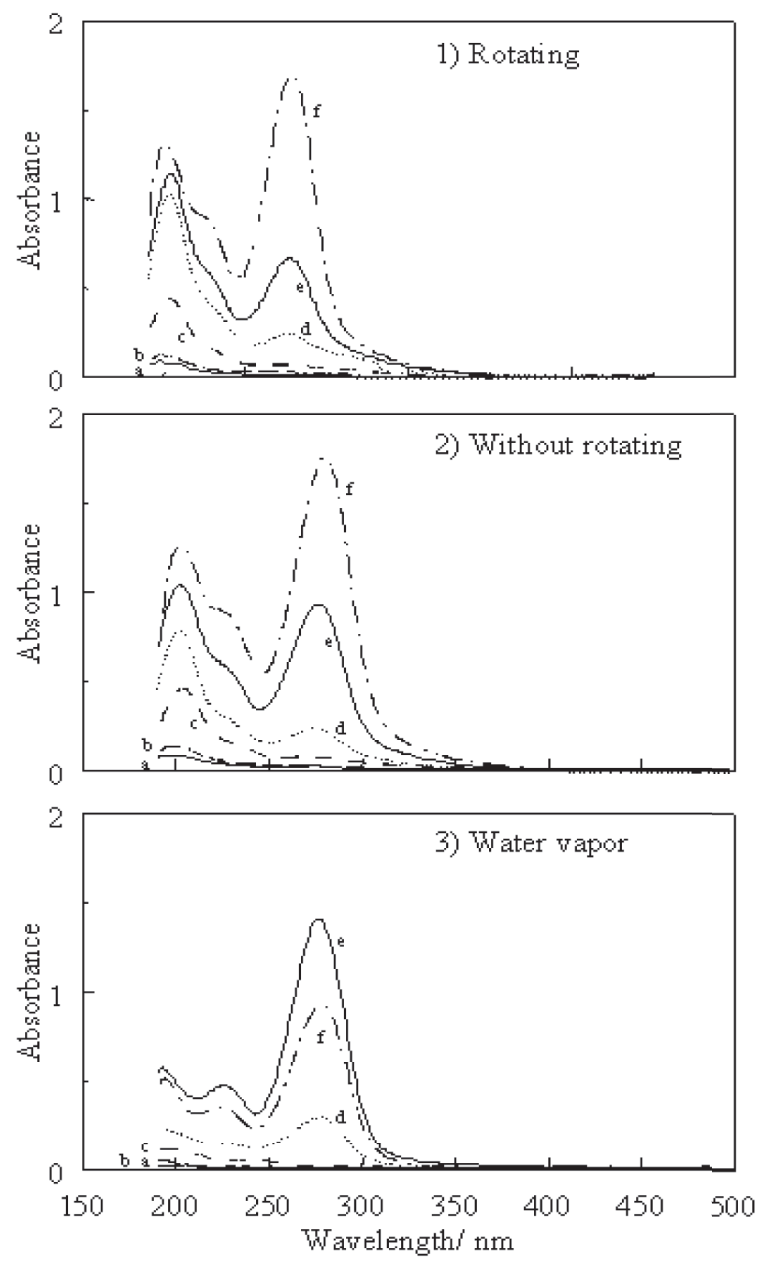

Fig. 10 Ultraviolet spectra for the bath after the hydrothermal treatment for $1 \mathrm{~h}$ at a, 120 ; b, 140 ; c, 160 ; d, 180 ; e, 200 ; f, $220{ }^{\circ} \mathrm{C}$.

要なカルシウムの溶出をある程度抑えながら柔細胞を除 去することが可能であることが示された。 なお，今回の 結果は, ケナフ勒皮組織中のリグニン量が $2 \%$ 程度 [12] に過ぎないことが影響したのではないかと考えられるた め, 今後は, リグニンリッチなケナフの芯部についても, 水蒸気処理の効果を検討していく予定である.

付記 : 研究に用いた ICP 発光分析装置は平成 11 年度日 本自転車振興会補助金, 密閉式高温高圧水反応処理装置 は平成 13 年度日本自転車振興会補助金, 蛍光 $\mathrm{X}$ 線分析装 置は平成 19 年度日本自転車振興会補助金を受けて設置し た物件であり，付記して謝意を表します。

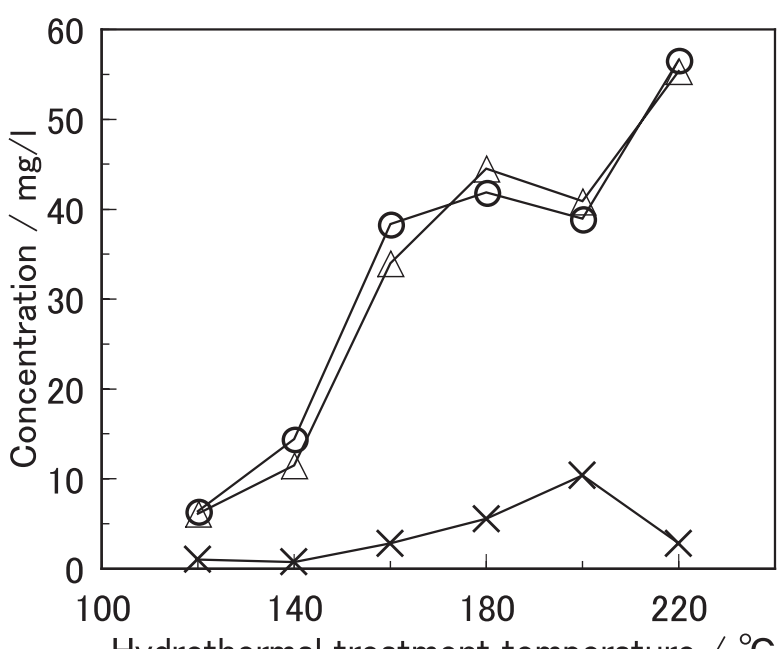

Hydrothermal treatment temperature $/{ }^{\circ} \mathrm{C}$

Fig. 11 Concentration of calcium contents estimated from ICP-AES measurements for the bath after hydrothermal treatment of kenaf fibers for $1 \mathrm{~h}$ : $\bigcirc$, with rotating; $\triangle$, without rotating the vessel; $\times$, in water vapor stream.

\section{文 献}

1. A. K. Bledzki, S. Reihmane and J. Gassan, Polym. Plast. Technol. Eng., 37(4), 451 (1998).

2. A. K. Bledzki and J. Gassan, Prog. Polym. Sci., 24, 221 (1999).

3. Y. Kawahara, K. Tadokoro, R. Endo, M. Shioya, Y. Sugimura, and T. Furusawa, Sen'i Gakkaishi, 61, 115 (2005).

4. Y. Kawahara, Y. Kawata, R. Endo, H. Minami, and S. Nishiuchi, Sen 'i Gakkaishi, 61, 142 (2005).

5. A. C. Mukherjiee and U. Mukhopadhyay, Text. Res. J., 53, 473 (1983).

6. N. L. Owen and D. W. Thomas, Appl. Spectrosc., 43, 451 (1989).

7. N. N. Das, S. C. Das and A. K. Mukherjee, Carbohydr. Res., 127, 345 (1984).

8. N. N. Das, S. C. Das, A. S. Dutt and A. Roy, Carbohydr. Res., 94, 73 (1981).

9. S. Shimizu, "Shokubutsu Seirigaku”, Shokabo, Tokyo, pp.122-123 (2002).

10. H. Abe, "Mokuzai kogyo Handbook", Maruzen, Tokyo, p.145 (1982).

11. T. Yamasaki, K. Hata, and T. Higuchi, Mokuzai Gakkaishi, 19, 299 (1973).

12. W. H. Morrison III, D. E. Akin, D. Archibald, and P. L. Raymer, "Kenaf properties, processing and products", (T. Sellers Jr., N. A. Reichert, Eds), Mississippi State Univ., p.173 (1999). 